\title{
SULUH
}

JURNAL BIMBINGAN DAN KONSELING

\section{METODE BELAJAR AKTIF MODEL PENGAJARAN TERARAH DAPAT MENINGKATKAN PRESTASI DAN PEIMAHAMAN PELAJARAN IPS PADA SISWA KELAS IV}

Active Learning Methods Directed Teaching Model Can Improve Achievement and Understanding of Social Studies Lessons in Grade IV Students 'Lili Kristiani

SDN II Palangka, Palangka Raya, Kalimantan Tengah, Indonesia.

\section{ARTIKEL INFO}

Diterima

Agustus 2021

Dipublikasi

September 2021

*e-mail :

lilikristiani65@gmail.com

\section{ABSTRAK}

Ada kecenderungan dalam dunia pendidikan dewasa ini untuk kembali pada pemikiran bahwa anak akan belajar lebih baik jika lingkungan diciptakan secara alamiah. Belajar akan lebih bermakna jika anak "mengalami" sendiri apa yang dipelajarinya, bukan 'mengetahui'-nya. Pembelajaran yang berorientasi target penguasaan materi terbukti berhasil dalam kompetisi 'mengingat' jangka pendek, tetapi gagal dalam membekali anak memecahkan persoalan dalam kehidupan jangkan panjang. Tujuan dari penelitian ini adalah Ingin mengetahui peningkatan prestasi belajar IPS setelah diterapkannya metode belajar aktif model pengajaran terarah dan Ingin mengetahui pengaruh motivasi belajar IPS setelah diterapkan metode belajar aktif model pengajaran terarah.

Penelitian ini menggunakan penelitian tindakan (action research) sebanyak 3 putaran. Setiap putaran terdiri dari empat tahap yaitu: rancangan, kegiatan dan pengamatan, refleksi, dan refisi. Sasaran penelitian ini adalah siswa kelas IV SDN II Palangka Kota Palangka Raya. Data yang diperoleh berupa hasil tes formatif, lembar observasi kegiatan belajar mengajar.

Dari hasil analis didapatkan bahwa prestasi belajar siswa mengalami peningkatan dari siklus I sampai siklus III yaitu, siklus I (65,63\%), siklus II (75,00\%), siklus III (I00\%). Simpulan dari penelitian ini adalah metode belajar aktif model pengajaran terarah dapat berpengaruh positif terhadap motivasi belajar Siswa SDN II Palangka Palangka Raya, serta model pembelajaran ini dapat digunakan sebagai salah satu alternatif pembelajaran IPS.

Kata kunci: IPS, Metode Belajar Aktif, Model Pengajaran Terarah.

\section{ABSTRACT}

There is a tendency in the world of education today to return to the idea that children will learn better if the environment is created naturally. Learning will be more meaningful if the child "experiences" himself what he learns, not "knows" it. Targetoriented learning to master the material has proven successful in short-term 'remembering' competitions, but fails to equip children to solve problems in long-term life. The purpose of this study was to find out the increase in social studies learning achievement after the application of the directed teaching model active learning method and to know the effect of social studies learning motivation after the active learning directed teaching model was applied.

This study uses three rounds of action research. Each round consists of four stages, namely: design, activities and observations, reflection, and revision. The target of this research is the fourth grade students of SDN II Palangka, Palangka Raya City. The data obtained in the form of formative test results, observation sheets of teaching and learning activities.

From the results of the analysis, it was found that student achievement increased from cycle I to cycle III, namely, cycle I (65.63\%), cycle II (75.00\%), cycle III (I00\%). The conclusion of this research is that the active learning method of the directed teaching model can have a positive effect on the learning motivation of SDN II Palangka Palangka Raya students, and this learning model can be used as an alternative for social studies learning.

Keywords: Social Studies, Active Learning Methods, Guided Teaching Model.

(C) Universitas Muhammadiyah Palangkaraya 
Jurnal Bimbingan dan Konseling

\section{PENDAHULUAN}

Tidak semua siswa memiliki kemampuan untuk fokus belajar mengajar dalam jangka waktu yang relatif lama. Siswa menyerap berbagai materi yang diberikan, ada yang cepat, ada yang sedang, dan ada yang lambat. Faktor inteligensi berpengaruh terhadap penguasaan siswa terhadap mata pelajaran yang diberikan oleh guru. Kecepatan siswa menerima mata pelajaran yang diberikan membutuhkan berbagai penghargaan untuk mendapatkan kontrol penuh.

Sebuah strategi pedagogis yang sempurna diperlukan untuk mengatasi perbedaan tersebut dalam kinerja siswa. Metode ini adalah jawabannya. Untuk siswa dalam satu kelompok, guru menggunakan metode tanya jawab untuk membantu menyerap isi pelajaran, sedangkan untuk siswa dalam kelompok lain, guru menggunakan metode tanya jawab untuk memudahkan pembelajaran isi pelajaran. Dapat diserap. Silakan gunakan ilustrasi. Atau metode eksperimental.

Oleh karena itu, Roestiyah, N.K. Menurut (1989: I). Salah satu langkah dalam strategi tersebut adalah dengan mempelajari teknik presentasi atau yang lebih sering disebut dengan metode mengajar. Menggunakan metode ini, pedagogi menandakan strategi pendidikan sebagai sarana untuk mencapai tujuan yang diperlukan.

Lingkungan pendidikan global saat ini memiliki kesamaan yang kembali ke gagasan bahwa anak-anak belajar paling baik ketika lingkungan diciptakan secara alami. Belajar menjadi lebih bermakna ketika anak "mengalami" dan "tidak mengetahui" apa yang telah dipelajarinya. Pembelajaran berorientasi tujuan untuk menguasai subjek telah terbukti efektif dalam kompetisi "memori" jangka pendek, tetapi tidak memberikan anak-anak keterampilan pemecahan masalah jangka panjang. Dan itulah yang terjadi di kelas kami! Pendekatan doktrin kontekstual (CTL) adalah pendekatan pedagogis yang ditandai dengan kepuasan harapan tersebut. Pendidikan kontekstual saat ini adalah dasar dari harapan para profesional pendidikan dan pendidikan untuk secara linguistik "menyala" ruang kelas. Pelajaran "langsung" diperlukan untuk mengikuti perubahan yang terjadi di luar sekolah dan yang terjadi dengan sangat cepat.

Mengajar bukan hanya berbicara. Belajar bukanlah hasil otomatis dari pembobotan informasi dalam pikiran siswa. Pembelajaran membutuhkan keterlibatan intelektual dan profesional siswa. Hanya menjelaskan dan mendemonstrasikan tidak membawa hasil belajar yang langgeng. Hanya kegiatan belajar aktif yang dapat menghasilkan hasil belajar yang langgeng. Apa itu belajar aktif? Siswa harus mengerjakan banyak pekerjaan rumah untuk belajar aktif. Mereka harus menggunakan otak mereka untuk menghasilkan ide, memecahkan masalah, dan menerapkan apa yang telah mereka pelajari. Pembelajaran aktif harus gesit, menyenangkan, bersemangat, dan penuh kasih. Siswa sering bangkit dari tempat duduknya, bergerak bebas dan berpikir dua kali (bergerak, berpikir keras). Untuk mempelajari sesuatu dengan baik, Anda harus mendengarkan, melihat, bertanya, dan berdiskusi dengan orang lain. Tidak hanya itu, siswa harus "melakukan". Artinya, Anda perlu menjelaskan berbagai hal dengan cara Anda sendiri, berbagi contoh, melatih keterampilan Anda, dan menyelesaikan tugas yang memerlukan pengetahuan yang Anda miliki atau perlu Anda peroleh.

Setiap orang akan mengajar, guru harus siap mengajar untuk melaksanakan sebagian dari rencana bulanan dan tahunan mereka. Persiapan meliputi rincian, tujuan instruksional, item instruksional kunci, metode pengajaran, bahan ajar, alat bantu visual, dan metode penilaian yang digunakan. 
Oleh karena itu, setiap guru secara efektif memutuskan dan memutuskan secara spesifik metode pengajaran sesuai dengan tujuan pengajaran, tujuan yang ingin dicapai, pemilihan alat peraga, pemilihan, metode penggunaan, metode pelaksanaan, tes, metode. dari penggunaan mereka. Anda harus memiliki pengetahuan yang baik, dan pengetahuan tentang arti penilaian.

Di sisi lain, keterampilan akademik merupakan aspek yang sering diabaikan oleh beberapa pendidik, terutama bagi mereka yang meragukan bahwa pendidik, sarana dan prasarana adalah yang terpenting. Padahal, dalam hal menyelam, semua pembelajaran di semua jenjang pendidikan, terutama sekolah dasar, menjadi calon individu tunggal sebagai entitas sosial dan berfokus pada kebutuhan.perkembangan anak perlu menjadi orang Indonesia yang harus dimiliki oleh para calon. Hal ini dapat tercapai jika dalam kegiatan belajar mengajar, guru selalu menggunakan teknologi pembelajaran yang mengacu pada pembelajaran terstruktur dalam penyampaian materi dan benar-benar diserap oleh siswa atau siswa secara bermakna.

Khusus dalam penelitian IPS, guru memulai pelajaran dengan memberikan istilahistilah penting dan tujuan yang ingin dicapai, kemudian membiasakan siswa dengan materi yang disampaikan guru, pembelajaran kontekstual. Ajukan pertanyaan kepada siswa. Tujuan penelitian untuk mengetahui peningkatan hasil belajar IPS setelah diterapkannya metode active learning model direct education pada siswa kelas

SDN II Palangka. Mengetahui pengaruh motivasi belajar setelah aktif mempelajari mata pelajaran IPS. Model pembelajaran langsung model pembelajaran telah diterapkan.

Pembelajaran merupakan proses, cara, membuahkan orang atau makhluk hayati belajar. Sedangkan belajar merupakan berusaha memperoleh kemampuan berpikir atau ilmu, berubah tingkah laris atau tanggapan yang ditimbulkan sang pengalaman. (KBBI, 1996:14). Konsep motivasi artinya Pengajaran tradisional menitik beratkan dalam metode imposisi, yakni pedagogi menggunakan cara menuangkan hal-hal yang dipercaya krusial sang pengajar bagi murid (Hamalik, 200I:157). Cara ini nir mempertimbangkan apakah bahan pelajaran yang diberikan itu sinkron atau nir menggunakan kesanggupan, kebutuhan, minat, \& taraf kesanggupan, dan pemahaman murid. Tidak jua diperhatikan apakah bahan-bahan yang diberikan itu berdasarkan atas motifmotif \& tujuan yang terdapat dalam murid.

sejak adanya penemuan-penemuan baru pada bidang psikologi tentang kepribadian dan tingkah laris manusia, dan perkembangan dalam bidang ilmu pendidikan maka pandangan tadi kemudian berubah. Faktor siswa didik justru sebagai unsur yang menentukan berhasil atau tidaknya pedagogi berdasarkan "pusat minat" anak makan, sandang, permainan/bekerja. kemudian menyusul tokoh pendidikan lainnya mirip Dr. John Dewey, yang terkenal dengan "pedagogi proyeknya”, yang berdasarkan di duduk perkara yang menarik minat peserta didik, sistem perekolahan lainnya. sehingga semenjak itu jua para ahli beropini, bahwa tingkah laris manusia didorong sang motifmotif eksklusif, serta perbuatan belajar akan berhasil bila didasarkan pada motivasi yang terdapat pada murid. siswa dapat dipaksa buat mengikuti seluruh perbuatan, tetapi ia tidak dapat dipaksa buat menghayati perbuatan itu sebagaimana mestinya. Seekor kuda dapat digiring ke sungai namun tidak dapat dipaksa untuk minum.Demikian pula juga halnya dengan murid, guru dapat memaksakan bahan pelajaran kepada mereka, akan tetapi guru tidak mungkin dapat memaksanya untuk belajar belajar dalam arti sesungguhnya. Inilah yng menjadi tugas yang paling berat yakni 
Jurnal Bimbingan dan Konseling

bagaimana caranya berusaha agar murid mau belajar, dan memiliki keinginan untuk belajar secara lanjutan. Sedangkan dari Djamarah (2002: I14) motivasi merupakan suatu pendorong yang mengubah tenaga pada diri seorang kedalam bentuk aktivitas konkret buat mencapai tujuan tertentu. dalam proses belajar, motivasi sangat dibutuhkan sebab seorang yang tidak mempunyai motivasi dalam belajar tidak akan mungkin melakukan kegiatan belajar. Hal ini sinkron menggunakan yang diungkapkan oleh Nur (200I:tiga) bahwa peserta didik yang termotivasi pada belajar sesuatu akan menggunakan proses kognitif yang lebih tinggi dalam mempelajari materi itu, sebagai akibatnya peserta didik itu akan menyerap dan mengendapkan materi itu dengan lebih baik.

Jadi motivasi artinya suatu syarat yang mendorong seseorang buat berbuat sesuatu dalam mencapai tujuan tertentu. dari jenisnya motivasi dibedakan sebagai dua, Motivasi Intrinsik serta Motivasi Ekstrinsik. Motivasi instrinsik adalah bahwa motivasi instrinsik adalah motivasi yang ada asal pada individu yang berfungsinya tidak perlu dirangsang berasal luar. seseorang yang memiliki motivasi intrinsik dalam dirinya maka secara sadar akan melakukan suatu aktivitas yang tak memerlukan motivasi asal luar dirinya.Sedangkan,motivasi ekstrinsik adalah motivasi yang ada berasal luar individu yang berfungsinya karena adanya perangsang berasal luar, contohnya adanya persaingan, buat mencapai nilai yang tinggi, dan lain sebagainya.3pertanyaan sederhana ini berbicara banyak tentang perlunya metode belajar aktif.

Yang saya dengar, saya lupa.

Yang saya dengar dan lihat, saya sedikit ingat.

Yang saya dengar, lihat, dan pertanyakan atau diskusikan dengan orang lain, saya mulai pahami. Dari yang saya dengar, lihat, bahas dan terapkan, saya dapatkan pengetahun dan keterampilan. Yang saya ajarkan kepada orang lain, saya kuasai. (Silberman, 2004:15).

Ada sejumlah alasan mengapa sebagian besar orang cenderung lupa tentang apa yang mereka dengar. Salah satu alasan yang paling menarik ada kaitannya dengan tingkat kecepatan bicara guru dan tingkat kecepatan pendengaran siswa.

pada umumnya pengajar berbicara dengan kecepatan 100 sampai 200 kata permenit. namun beberapa kata-istilah yang mampu ditangkap peserta didik dalam per menitnya? Ini tentunya juga bergantung pada cara mereka mendengarkannya. Jika siswa benar-sahih berkonsentrasi, mereka akan dapat mendengarkan dengan penuh perhatian terhadap 50 sampai 100 kata per mnt, atau I/2 dari apa yang dikatakan guru. Itu sebab siswa jua berpikir banyak selama mereka mendengarkan. Akan sulit menyimak guru yang bicaranya nyerocos. besar kemungkinan, peserta didik tidak mampu konsentrasi sebab, sekalipun materinya menarik, berkonsentrasi dalam ketika yang lama memang bukan masalah praktis. Penelitian membagikan bahwa siswa mampu mendengarkan (tanpa memikirkan) menggunakan kecepatan 400 sampai 500 istilah per mnt. waktu mendengarkan pada waktu berkepanjangan terhadap seseorang pengajar yang berbicara lambat, siswa cenderung menjadi jenuh, serta pikiran mereka mengembara entah ke mana.

Bahkan, sebuah penelitian membagikan bahwa pada suatu perkualiahan bergayaceramah, mahasiswa kurang memberikan perhatian selama $40 \%$ asal semua ketika kuliah (Pollio, 1984) (dalam Sileberman, 2004:16. Mahasiswa bisa mengingat 70 persen dalam sepuluh mnt pertama kuliah, sedangkan pada sepuluh mnt terakhir, mereka hanya dapat mengingat 20\% materi kuliah mereka (McKeachie, 1986) (di Silberman, 2004:16). tidak heran Jika mahasiswa pada kualiah psikologi yang disampaikan memakai gaya ceramah hanya mengetahui $8 \%$ lebih poly asal 
kelompok pembanding yang sama sekali belum pernah mengikuti kuliah itu (Richard, dkk., 1989) (dalam Silberman, 2004:16). Bayangkan apa yang mampu dihasilkan dari hadiah kuliah memakai cara mirip itu pada perguruan tinggi. dalam teknik ini, guru mengajukan satu atau beberapa pertanyaan buat melacak pengetahuan siswa atau menerima hipotesis atau simpulan mereka dan lalu memilah-milahnya menjadi sejumlah kategori. Metode pengajaran terarah ialah selingan yang mengasyikan di sela-sela cara pengajaran biasa. Cara ini memungkinkan pengajar buat mengetahui apa yang telah diketahui serta dipahami oleh peserta didik sebelu memaparkan apa yang guru ajarkan. Metode ini sangat berguna pada mengajarkan konsep-konsep abstrak.

\section{METODOLOGI PENELITIAN}

Penelitian ini merupakan penelitian tindakan (action research), karena penelitian dilakukan untuk memecahkan masalah pembelajaran di kelas. Penelitian ini juga termasuk penelitian deskriptif, sebab menggambarkan bagaimana suatu teknik pembelajaran diterapkan dan bagaimana hasil yang diinginkan dapat dicapai.

Menurut Sukidin dkk. (2002:54) ada 4 macam bentuk penelitian tindakan, yaitu: (I) penelitian tindakan guru sebagai peneliti, (2) penelitian tindakan kolaboratif, (3) penelitian tindakan simultan terintegratif, dan penelitian tindakan sosial eksperimental.

Keempat bentuk penelitian tindakan pada atas, terdapat persamaan serta perbedaannya. berdasarkan Oja serta Smulyan sebagaimana dikutip oleh Kasbolah, (pada Sukidin, dkk. 2002:55), 83ac9cb3e4459a85df0cacfb819e6b77 dari setiap penelitian tergantung di: (I) tujuan utamanya atau pada tekanannya, (dua) tingkat kerja sama antara pelaku peneliti serta peneliti berasal luar, (3) proses yang dipergunakan dalam melakukan penelitian, dan (4) korelasi antara proyek menggunakan sekolah.

dalam penelitian ini menggunakan bentuk penelitian tindakan kolaboratif, dimana peneliti bekerja sama dengan kepala sekolah dan guru kelas. Tujuan utama penelitian tindakan kelas adalah buat menaikkan praktikpraktik pembelajaran di kelas. pada kegiatan ini, seluruh yang tergabung dalam penelitain ni terlibat langsung secara penuh pada proses perencanaan, tindakan, observasi, serta refleksi. Kehadiran pihak lain pada penelitian ini peranannya tidak secara umum dikuasai serta sangat kecil. kawasan penelitian ialah kawasan yang dipergunakan pada melakukan penelitian untuk memperoleh data yang diinginkan. Penelitian ini bertempat pada SDN I I Palangka Kota Palangka Raya.

\section{HASIL DAN PEMBAHASAN}

Data penelitian yang diperoleh merupakan data observasi berupa pengamatan pengelolaan belajar aktif serta pengamatan kegiatan peserta didik serta pengajar di akhir pembelajaran, dan data tes formatif siswa pada setiap daur.

Data lembar observasi diambil asal dua pengamatan yaitu data pengamatan pengelolaan pembelajaran metode pedagogi terarah yang dipergunakan buat mengetahui pengaruh penerapan metode pedagogi terarah pada menaikkan prestasi. Data tes formatif buat mengetahui peningkatan prestasi belajar siswa setelah diterapkan belajar aktif.

\section{Siklus I}

Dalam hal ini peneliti bertindak sebagai pengamat dengan dibantu oleh kepala sekolah SDN II Palangka Kota Palangka Raya, Propinsi Kalimantan Tengah Tahun Pelajaran, sedangkan yang bertindak sebagai pengajar adalah guru kelas SDN II Palangka Kota Palangka Raya, Propinsi Kalimantan Tengah. Adapun proses belajar mengajar mengacu pada rencana pelajaran yang telah 
dipersiapkan. Pengamatan (observasi) dilaksanakan bersamaan dengan pelaksaaan belajar mengajar.

Pada akhir proses belajar mengajar siswa diberi tes formatif I menggunakan tujuan buat mengetahui tingkat keberhasilan siswa pada proses belajar mengajar yang telah dilakukan. hasil observasi berikutnya adalah kegiatan guru dan siswa berdasarkan data tampak bahwa kegiatan guru yang paling lebih banyak didominasi di siklus I adalah membimbing dan mengamati siswa dalam menemukan konsep yaitu $21,7 \%$. aktivitas lain yang persentasenya relatif akbar merupakan memberi umpan pulang/evaluasi/tanya jawab serta menyebutkan materi yang sulit yaitu masing-masing sebanyak $18,3 \%$ dan $13,3 \%$. Sedangkan kegiatan peserta didik yang paling lebih banyak didominasi merupakan mengerjakan/memperhatikan penerangan guru yaitu $22,5 \%$. aktivitas lain yang persentasenya relatif besar merupakan bekerja dengan sesama anggota kelompok, diskusi antar siswa/antara peserta didik dengan guru, dan membaca kitab yaitu masing-masing $18,7 \%$ 14,4 dan II,5\%.

pada siklus I, secara garis besar aktivitas belajar mengajar dengan merapkan metode pedagogi terarah telah dilaksanakan menggunakan baik, walaupun kiprah guru masih cukup lebih banyak didominasi buat memberikan penerangan dan arahan karena contoh tadi masih dirasakan baru oleh siswa. serta berdasarkan data tampak bahwa aktivitas guru yang paling secara umum dikuasai di siklus I ialah membimbing serta mengamati peserta didik dalam menemukan konsep yaitu $21,7 \%$. kegiatan lain yang persentasenya relatif akbar artinya memberi umpan kembali/penilaian/tanya jawab dan menjelaskan materi yang sulit yaitu masingmasing sebanyak 18,tiga\% dan 13,tiga\%. Sedangkan kegiatan peserta didik yang paling mayoritas artinya mengerjakan/memperhatikan penerangan guru yaitu 22,lima\%. kegiatan lain yang persentasenya relatif akbar merupakan bekerja dengan sesama anggota gerombolan, diskusi antar siswa/antara siswa menggunakan guru, serta membaca buku yaitu masingmasing $18,7 \% \backslash 14,4$ serta $11,5 \%$.

Pada siklus I, secara garis besar kegiatan belajar mengajar menggunakan merapkan metode pedagogi terarah telah dilaksanakan dengan baik, walaupun kiprah guru masih cukup secara umum dikuasai untuk menyampaikan penjelasan serta arahan karena model tersebut masih dirasakan baru oleh siswa.

dalam aplikasi aktivitas belajar mengajar diperoleh info berasal yang akan terjadi pengamatan menjadi berikut:

I. Guru Kurang Baik Pada Memotivasi Peserta Didik Serta Dalam Memberikan Tujuan Pembelajaran

2. Pengajar Kurang Baik Dalam Pengelolaan Waktu

3. Peserta Didik Kurang Begitu Antusias Selama Pembelajaran berlangsung.

\section{Siklus II}

Berasal data yang didapat, tampak aspek-aspek yang diamati di kegiatan belajar mengajar (siklus II) yang dilaksanakan sang guru dengan menerapkan metode pengajaran terarah menerima penilaian yang cukup baik dari pengamat. Maksudnya berasal seluruh evaluasi tak ada nilai kurang. Namum demikian evaluasi tadi belum artinya akibat yang optimal, buat itu terdapat beberapa aspek yang perlu menerima perhatian buat penyempurnaan penerapan pembelajaran selanjutnya. Aspek-aspek tersebut merupakan memotivasi siswa, membimbing peserta didik merumuskan kesimpulan/ menemukan konsep, dan pengelolaan waktu.

Menggunakan penyempurnaan aspekaspek di atas pada penerapan metode pengajaran terarah diperlukan siswa bisa menyimpulkan apa yang sudah mereka pelajari serta mengemukakan pendapatnya sebagai 
Jurnal Bimbingan dan Konseling

akibatnya mereka akan lebih tahu perihal apa yang sudah mereka lakukan.

Asal data yang didapat, tampak aspekaspek yang diamati di kegiatan belajar mengajar (daur II) yang dilaksanakan sang guru dengan menerapkan metode pengajaran terarah menerima penilaian yang relatif baik berasal pengamat. Maksudnya asal seluruh penilaian tidak ada nilai kurang. Namum demikian penilaian tadi belum adalah akibat yang optimal, buat itu terdapat beberapa aspek yang perlu menerima perhatian untuk penyempurnaan penerapan pembelajaran selanjutnya. Aspek-aspek tersebut adalah memotivasi siswa, membimbing siswa merumuskan kesimpulan/ menemukan konsep, serta pengelolaan ketika.

Menggunakan penyempurnaan aspekaspek pada atas dalam penerapan metode pengajaran terarah diharapkan peserta didik dapat menyimpulkan apa yang sudah mereka pelajari dan mengemukakan pendapatnya menjadi akibatnya mereka akan lebih tahu wacana apa yang telah mereka lakukan. Berikutnya adalah rekapitulasi akibat tes formatif peserta didik dari data yang diperoleh nilai rata-homogen prestasi belajar siswa ialah 75,31 dan ketuntasan belajar mencapai $75,00 \%$ atau ada 18 peserta didik asal 22 siswa sudah tuntas belajar. yang akan terjadi ini menunjukkan bahwa pada siklus II ini ketuntasan belajar secara klasikal sudah mengalami peningkatan sedikit lebih baik berasal siklus I. Adanya peningkatan akibat belajar siswa ini karena setelah pengajar menginformasikan bahwa setiap akhir pelajaran akan selalu diadakan tes sebagai akibatnya di rendezvous berikutnya siswa lebih termotivasi buat belajar. Selain itu peserta didik jua sudah mulai mengerti apa yang dimaksudkan serta dinginkan guru memakai menerapkan metode belajar aktif contoh pengajaran terarah.

\section{Siklus III}

Sesuai data tampak bahwa kegiatan pengajar yang paling lebih banyak didominasi pada siklus III merupakan membimbing dan mengamati siswa pada menemukan konsep yaitu 22,6\%, sedangkan aktivitas mengungkapkan materi yang sulit serta memberi umpan pulang/penilaian/tanya jawab menurun masing-masing sebesar $(10 \%)$ serta (II,7\%). kegiatan lain yang mengalami peningkatan artinya mengaitkan menggunakan pelajaran sebelumnya (10\%), memberikan materi/strategi /langkah-langkah (13,tiga\%), meminta peserta didik menyajikan dan mendiskusikan yang akan terjadi kegiatan (10\%), dan membimbing siswa merangkum pelajaran (10\%). Adapun kegiatan yang tidak mengalami perubaan ialah menyampaikan tujuan $(6,7 \%)$ serta memotivasi peserta didik $(6,7 \%)$.

Sedangkan buat aktivitas siswa yang paling dominan di siklus III adalah Bekerja dengan sesama anggota grup yaitu (22,1\%) serta mendengarkan/menperhatikan penerangan pengajar $(20,8 \%)$, aktivitas yang mengalami peningkatan ialah membaca buku siswa $(13,1 \%)$ serta diskusi antar peserta didik/antara peserta didik menggunakan pengajar (15,0\%). Sedangkah aktivitas yang lainnya mengalami penurunan. Berikut artinya rekapitulasi hasil tes formatif siswa, sesuai yang diperoleh nilai rata-homogen tes formatif sebesar 80,31 dan dari 22 peserta didik yang sudah tuntas sebesar 22 peserta didik. Maka secara klasikal ketuntasan belajar yang sudah tercapai sebesar $100 \%$.yang akan terjadi di daur III ini mengalami peningkatan lebih baik asal daur II. Adanya peningkatan yang akan terjadi belajar pada siklus III ini dipengaruhi sang adanya peningkatan kemampuan pengajar pada menerapkan belajar aktif sehingga peserta didik menjadi lebih terbiasa dengan pembelajaran seperti ini sebagai akibatnya peserta didik lebih simpel 
Jurnal Bimbingan dan Konseling

pada memahami materi yang telah diberikan.

pada tahap ini akan dikaji apa yang sudah terlaksana dengan baik juga yang masih kurang baik pada proses belajar mengajar dengan penerapan belajar aktif. berasal datadata yang sudah diperoleh dapat diuraikan sebagai berikut:

I. Selama proses belajar mengajar guru sudah melaksanakan semua pembelajaran dengan baik. Meskipun ada beberapa aspek yang belum sempurna, tetapi persentase pelaksanaannya buat masing-masing aspek relatif besar.

2. sesuai data yang akan terjadi pengamatan diketahui bahwa siswa aktif selama proses belajar berlangsung.

3. Kekurangan pada daur-daur sebelumnya sudah mengalami perbaikan dan peningkatan sehingga menjadi lebih baik.

4. yang akan terjadi belajar siswsa pada daur III mencapai ketuntasan.

Melalui yang akan terjadi penelitian ini menunjukkan bahwa metode belajar aktif contoh pengajaran terarah memiliki akibat positif dalam menaikkan prestasi belajar siswa. Hal ini mampu dipandang dari semakin mantapnya pemahaman peserta didik terhadap materi yang disampaikan guru (ketuntasan belajar semakin tinggi dari siklus I, II, serta III) yaitu masing-masing 65,63\%, $75,00 \%$, serta $100 \%$. di daur III ketuntasan belajar siswa secara klasikal telah tercapai. Kemampuan guru pada Mengelola Pembelajaran berdasarkan analisis data, diperoleh kegiatan siswa di proses belajar aktif dalam setiap siklus mengalami peningkatan. Hal ini berdampak positif terhadap prestasi belajar siswa yaitu bisa ditunjukkan memakai meningkatnya nilai ratarata siswa pada setiap daur yang terus mengalami peningkatan.

Aktivitas guru serta siswa pada Pembelajaran, sinkron analisis data, diperoleh aktivitas peserta didik dalam proses pembelajaran IPS pada primer bahasan perkembangan teknologi untuk produksi, komunikasi serta transportasi menggunakan metode belajar aktif model pengajaran terarah yang paling dominant ialah bekerja dengan memakaiindera/media,mendengarkan/memper hatikan guru, dan diskusi antar siswa/antara siswa dengan pengajar. Jadi mampu dikatakan bahwa aktivitas isiwa bisa dikategorikan aktif.

Sedangkan buat kegiatan guru selama pembelajaran sudah melaksanakan langkahlangkah belajar aktif memakai baik. Hal ini terlihat dari kegiatan guru yang ada di antaranya kegiatan membimbing serta mengamati peserta didik di mengerjakan aktivitas Lomba Kompetensi Siswa/menemukan konsep, menyebutkan materi yang tidak dimengerti, memberi umpan kembali /evaluasi/tanya jawab dimana prosentase untuk kegiatan pada atas relatif besar.

\section{KESIMPULAN}

Dari yang akan terjadi kegiatan pembelajaran yang sudah dilakukan selama tiga siklus, serta sesuai seluruh pembahasan dan analisis yg telah dilakukan bisa disimpulkan sebagai berikut:

I. Pembelajaran dengan metode belajar aktif model pengajaran terarah mempunyai akibat positif dalam menaikkan prestasi belajar peserta didik yg ditandai menggunakan peningkatan ketuntasan belajar peserta didik dalam setiap siklus, yaitu daur I (65,63\%), daur II (75,00\%), daur III (I00\%).

2. Penerapan metode belajar aktif contoh pengajaran terarah mempunyai impak positif, yaitu bisa mempertinggi motivasi belajar siswa yang ditunjukan dengan ratahomogen jawaban siswa yang menyatakan bahwa siswa tertarik serta berminat dengn metode belajar aktif model pengajaran terarah sehingga mereka menjadi termotivasi buat belajar. 
Jurnal Bimbingan dan Konseling

Saran buat melaksanakan belajar aktif memerlukan persiapan yg cukup matang, sebagai akibatnya guru harus mampu memilih atau menentukan topik yang sahih-sahih mampu diterapkan menggunakan metode belajar aktif model pengajaran terarah dalam proses belajar mengajar sehingga diperoleh yang akan terjadi yang optimal. sederhana, dimana peserta didik nantinya bisa menemukan pengetahuan baru, memperoleh konsep dan keterampilan, sebagai akibatnya peserta didik berhasil atau bisa memecahkan dilema-dilema yang dihadapinya.

\section{DAFTAR PUSTAKA}

Arikunto, Suharsimi. 1993. Manajemen Mengajar Secara Manusiawi. Jakarta: Rineksa Cipta.

Arikunto, Suharsimi. 2012. Dasar-dasar Evaluasi Pendidikan. Jakarta: Bumi Aksara.

Arikunto, Suharsimi. 2012. Prosedur Penelitian Suatu Pendekatan Praktek. Jakarta:Rineksa Cipta

Departemen Pendidikan dan Kebudayaan, 1994. Petunjuk Pelaksanaan Proses Belajar Mengajar, Jakarta. Balai Pustaka.

Djamarah, Syaiful Bahri. 2012. Strategi Belajar Mengajar. Jakarta: Rineksa Cipta.

Hadi, Sutrisno. 198I. Metodogi Research. Yayasan Penerbitan Fakultas Psikologi Universitas Gajah Mada. Yoyakarta.

Hamalik, Oemar. 1994. Metode Pendidikan. Bandung:Citra Aditya Bakti.

Hasibuan. J.J. dan Moerdjiono. 1998. Proses Belajar Mengajar. Bandung: Remaja Rosdakarya.

Hendri dan Yanti. 2015. Penerapan Metode Bermain Peran untuk Meningkatkan Hasil Belajar IPS Peserta Didik di SDNI Langkai Palangkaraya. Tunas Jurnal Pendidikan Guru Sekolah Dasar. I:I(3035).

Kemmis, S. dan Mc. Taggart, R. 1988. The
Action Research Planner. Victoria Dearcin University Press.

Margono. 1997. Metodologi Penelitian Pendidikan. Jakarta. Rineksa Cipta.

Mursell, James ( - ). Succesfull Teaching (terjemahan). Bandung: Jemmars.

Ngalim, Purwanto M. 1990. Psikologi Pendidikan. Bandung: Remaja Rosdakarya.

Nur, Moh. 200I. Pemotivasian Siswa untuk Belajar. Surabaya. University Press. Universitas Negeri Surabaya.

Putra, Chandra Anugrah dan M Andi Setiawan. 2019. Penerapan Model Pembelajaran Circuit Learning Berbantuan Media Power Point Terhadap Hasil Belajar IPS. Jurnal Bidang Pendidikan Dasar. 3:I (I-6).

Riadin Agung dan Ade Salahuddin Permadi. 2019. Implementasi Pembelajaran PKn untuk Membentuk Pribadi yang Berkarakter di SD Muhammadiyah Sampit. 14: I (18-28).

Rustiyah, N.K. 20II. Strategi Belajar Mengajar. Jakarta: Bina Aksara.

Sardiman, A.M. 2016. Interaksi dan Motivasi Belajar Mengajar. Jakarta: Bina Aksara.

Sukidin, dkk. 20I2. Manajemen Penelitian Tindakan Kelas. Insan Cendekia.

Suryosubroto, B. 1997. Proses Belajar Mengajar di Sekolah. Jakarta: Rineksa Cipta.

Usman, Moh. Uzer. 20II. Menjadi Guru Profesional. Bandung: Remaja Rosdakarya. 